\title{
Aylan Kurdi como imagem-despertador da crise dos refugiados: o enquadramento da imprensa ibérica
}

\author{
Rafael Mangana \\ Universidade da Beira Interior / LabCom.IFP \\ E-mail: rafael.mangana@labcom.ubi.pt
}

\begin{abstract}
Resumo
No contexto da crise dos refugiados, o dia 2 de setembro de 2015 marca de forma inequívoca a atenção dada a esta questão por parte dos media um pouco por todo o mundo. O aparecimento de um cadáver de uma criança síria de três anos numa praia turca contribuiu para transformar o enquadramento desta crise, que passou a ter um rosto, um nome, que se transformaram em ícone da mesma: Aylan Kurdi. Sem nos determos na comparação entre o antes e o depois deste acontecimento mediático, o intuito deste texto é, antes, analisar a forma como a imagem desta criança influenciou a cobertura mediática da crise dos refugiados nos momentos subsequentes. Serão apresentados, através de uma amostra de conveniência, quatro momentos específicos, significati-

enquadramento da crise dos refugiados, apoiando-se na imagem de Aylan Kurdi e naquilo que a mesma passou a representar. Este trabalho analisa momentos específicos das versões online de dois jornais classificados como de referência de Portugal e Espanha (Público e El País), num período fulcral da crise. Através da análise de discurso dos elementos jornalísticos recolhidos associada ao estudo dos efeitos de framing e de priming, pretende-se explorar a possibilidade de acrescentar mais um conceito aos que já existem no vasto campo das teorias dos efeitos dos media: o conceito de imagem-despertador, enquanto elemento que detona um conjunto de memórias e de conhecimentos latentes associados a um determinado tema, assunto ou protagonista.
\end{abstract} vos da forma como a imprensa ibérica procedeu ao

Palavras-chave: framing; priming; imagem-despertador; crise dos refugiados; migração; representações mediáticas.

\begin{abstract}
Considering the background of the refugee crisis, September 2, 2015 unequivocally marks the media coverage given to this issue around the world. The appearance of a corpse of a three-year-old Syrian child on a Turkish beach has greatly contributed to a different framework of the crisis that has come to

have a face and a name: Aylan Kurdi. Without setting a comparison between the before and after this media event, the purpose is to analyze how this event influenced media coverage of the refugee crisis in subsequent moments. Using a convenience sample will be analyzed four specific moments relying on
\end{abstract}

Data de submissão: 31/05/2017. Data de aprovação: 30/06/2017.

A Revista Estudos em Comunicação é financiada por Fundos FEDER através do Programa Operacional Factores de Competitividade - COMPETE e por Fundos Nacionais através da FCT - Fundação para a Ciência e a Tecnologia no âmbito do projeto Comunicação, Filosofia e Humanidades (LabCom.IFP) UID/CCI/00661/2013.
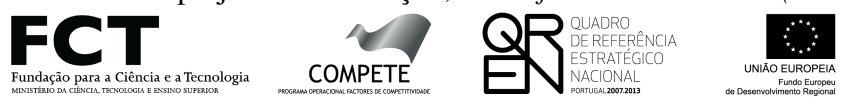

1) 
the image of Aylan Kurdi that seem significant to us of what this photo came to signify, during the framing process. This paper aims to extract the analysis of the online version of two quality newspapers from Portugal and Spain, at a time of the refugees' crisis. Through the discourse analysis of the collec- ted data related with framing and priming effects one tries to add a new concept to the many ones already existing in the field of effects theory: the concept of awakening-image, as an element that triggers a set of memories and latent knowledge associated with an issue, subject or protagonist.

Keywords: framing; priming; awakening image; refugee crisis; migration; media representations.

\title{
Introdução
}

\begin{abstract}
A EUROPA enfrenta, no início do século XXI, um crescimento exponencial do número de migrantes que chegam de outros países. Esta tendência foi acentuada desde 2015, com a chegada de refugiados provenientes, sobretudo, do Médio Oriente e Norte de África. Estes refugiados têm-se espalhado um pouco por todo o continente europeu, não sendo, no entanto, a sua chegada aceite de igual modo em todos os países. A animosidade em relação aos refugiados foi potenciada por atos terroristas, perpetrados em cidades representativas do poder político-económico europeu, como Paris, Londres ou Bruxelas. Deste modo, os refugiados têm sido, frequentemente, identificados como terroristas. Torna-se, assim, de especial interesse - recorrendo às teorias dos efeitos dos media -, saber de que modo os media abordam esta crise.

Neste contexto, tentaremos encontrar respostas para algumas questões que giram em torno da forma como os media constroem a realidade, enquadram ou recriam contextos, apresentando ideias associadas a preconceitos e a processos latentes que se manifestam mediante estímulos ou referências tipificadas.

Pretende-se, assim, fazer uma análise comparativa do tratamento dado a esta problemática pela imprensa portuguesa e espanhola considerada de referência.

Quanto ao objeto de análise - tendo em conta o desenrolar da crise dos refugiados na Europa afigura-se relevante debruçar esta reflexão sobre um momento crucial desta crise: o aparecimento do cadáver de uma criança síria, Aylan Kurdi, que deu à costa numa praia turca em setembro de 2015. Neste contexto, serão analisados alguns conteúdos noticiosos dos jornais Público (Portugal) e El País (Espanha). A escolha dos jornais dos dois países pareceu-nos interessante pela proximidade histórica e geográfica entre ambos, ainda que pontuada por diferenças culturais notórias.
\end{abstract}

\section{Framing: significado e evolução de um conceito}

A relevância da teoria do Enquadramento no vasto campo das Ciências Sociais é inegável, particularmente no âmbito das Ciências da Comunicação.

Tratando-se de uma metacomunicação, o enquadramento (ou framing) consiste num conjunto de regras, de instruções que dão lógica e que organizam o discurso, do mesmo modo que há na relação entre os indivíduos um determinado ordenamento e sentido nos comportamentos, códigos comummente aceites e que determinam a sua interação. É a este conjunto de regras que estruturam um comportamento ou um discurso que definimos como enquadramento. 
Num dos seus papers mais importantes sobre a teoria - Framing: Towards the Clarification of a Fractured Paradigm -, Robert Entman, resume esta ideia, defendendo que "enquadrar é seleccionar certos aspetos da realidade percebida e torná-los mais salientes no texto da comunicação de tal forma a promover a definição particular de um problema, de uma interpretação causal, de uma avaliação moral, e/ou a recomendação de tratamento para o tema descrito. Enquadramentos, tipicamente, diagnosticam, avaliam e prescrevem" (Entman, 1993:53).

Segundo McCombs e Ghanem (2001), "as origens do termo enquadramento no âmbito da Comunicação remetem-nos para a fotografia e para a cinematografia, onde enquadramento se refere a variáveis como o ângulo da câmara e a perspetiva no estilo de uma mensagem visual" (p.71).

O antropólogo e epistemólogo Gregory Bateson foi, nos anos 50, um dos pioneiros no uso da noção de frame no âmbito das Ciências Sociais e Humanas. Num dos seus mais importantes trabalhos, "A Theory Of Play and Fantasy" (1954; 1972), Bateson incide a sua análise sobre aquilo a que chama os "paradoxos de abstracção da comunicação verbal" (Bateson, 1972: 177), num âmbito metacomunicativo e metalinguístico, e utiliza o termo frame enquanto conceito psicológico, relacionando-o com a ideia de "contexto". Ou seja, o autor defende que enquadrar é circunscrever um determinado número de mensagens (ou ações significativas) que acabam por ganhar sentido, por ter lógica, numa determinada situação que é partilhada por todos os interlocutores.

Neste seu ensaio sobre psicologia da perceção, Bateson toma o frame como conceito psicológico, mas sublinha a importância das mensagens como elementos essenciais enquanto condicionadores da construção e definição do próprio conceito. Como nos faz notar o autor: "Qualquer mensagem que implícita ou explicitamente defina um enquadramento, ipso facto dá instruções ou ajudas ao receptor na sua tentativa de compreender as mensagens contidas no enquadramento" (1972: 188).

Bateson considera que enquadrar não é mais que circunscrever um conjunto de mensagens que ganham sentido para os interlocutores num contexto partilhado. Ou seja, o enquadramento ajuda-nos, por exemplo, a estabelecer a diferença entre a simulação e a realidade.

Anteriormente, num contexto de debate em torno da epistemologia das Ciências Sociais, o recurso a esquemas mentais latentes no indivíduo, fundamentais para a compreensão do ambiente circundante do ator social, fora utilizado a propósito da ideia de tipificação de Alfred Schutz (1979: 110). Na análise ao "mundo da vida", estes esquemas cognitivos fundam-se numa experimentação à priori do mundo e dos objetos que o compõem. Schutz defendeu a observação de ações típicas, coordenando-as com modelos construídos de agentes também típicos. A perceção do mundo da vida sociocultural só é possível mediante um processo de tipificação, enquanto processo de classificação de situações, de objetos, de contextos, tendo por base acontecimentos passados, os quais dão aos atores de acontecimentos futuros um "stock de conhecimentos" socialmente adquiridos, que permitem ao ator social, nos termos usados pelo próprio Schutz, "pensar como sempre".

Posteriormente, Erving Goffman (1974, fundando-se em Schutz) nos anos 70, lança um olhar mais sociológico sobre o conceito. $\mathrm{O}$ autor toma o frame enquanto quadro social e como esquema mental que permite organizar a experiência.

Com Goffman, há uma mudança do conceito original, desde um ponto de vista individual até um ponto de vista predominantemente coletivo, do psicológico ao sociológico, já que considera o frame um instrumento social que possibilita uma interpretação partilhada da realidade. Goffman 
enfatiza a forma como a realidade é interpretada pelos indivíduos e não tanto a realidade por si só, desenvolvendo-se a interação entre os quadros sociais e os esquemas mentais de cada indivíduo.

Diz-nos Goffman: "[A definição de uma] situação é construída em concordância com princípios de organização, os quais governam os acontecimentos - pelo menos os sociais - e o nosso envolvimento subjectivo neles; frame é a palavra que utilizo para me referir a tais elementos básicos..." (1974: 10 e 11).

É a Gay Tuchman (1978) que devemos o estudo do conceito de enquadramento adaptado ao campo do jornalismo. Utilizando os conceitos de tipificação de Schutz e de Goffman - que, como já foi explanado, encararam os frames como formas de organização da vida quotidiana visando a compreensão das situações sociais -, para dar resposta a estas situações sociais, a socióloga americana usa o referido conceito como sinónimo de ideia organizadora, utilizada na atribuição de sentido aos acontecimentos.

No seu desempenho rotineiro, o jornalista trabalha tendo em conta regras organizacionais que condicionam o campo de ação. Ao considerarmos que a consciência e o sentido de pertença a um grupo, neste caso profissional, se associam aos objetos da organização noticiosa, a produção de notícias considera-se construção social da realidade. O seu enquadramento forma-se por sequências da vida quotidiana, frames selecionados de uma atividade contínua e permanente.

Para Tuchman, as notícias não se restringem a espelhar a realidade, mas constroem-na, agindo dialeticamente. Ou seja, ao mesmo tempo que apresentam determinadas noções da realidade, concorrem para modificar a forma como essa realidade é percepcionada. As categorias da experiência social, os factos e as significações sociais são definidos pela "atitude natural", tal como Alfred Schutz a teorizou, e, desse modo, embora se apresentem como a-históricos e naturalmente reificados, são histórica e socialmente produzidos pelas interações sociais, pelas instituições sociais e, por conseguinte, pelas notícias. Estas, embora condicionadas e codificadas pelas instituições sociais continuarão, como conclui a autora, "a reproduzir-se a si mesmas como factos históricos indiscutíveis; não só definindo e redefinindo, constituindo e reconstituindo as significações sociais, mas também definindo e redefinindo, constituindo e reconstituindo modos de fazer coisas - os processos existentes nas instituições existentes" (1978: 182).

\section{Do priming à imagem-despertador}

O priming é estudado nos campos da psicologia social e da neuropsicologia há cerca de 50 anos, relacionando-se com a forma (inconsciente) como um determinado estímulo inicial influi nas respostas por parte do indivíduo a estímulos posteriores. Ou seja, trata-se de um processo mental segundo o qual o indivíduo vai buscar referências latentes na memória, fruto de experiências anteriormente vividas, para proceder à explicação de um dado tema e para a formação de opiniões.

Shanto Iyengar e Donald Kinder (1987) procedem às primeiras aplicações do conceito de priming à área da Comunicação. Os autores defendem que o priming diz respeito a alterações na forma como as pessoas avaliam os fenómenos políticos, no sentido lato. Durante este processo de avaliação, nomeadamente, de avaliação do comportamento e performance de um ator político, o 
indivíduo tende a recorrer a esquemas mentais padronizados, mediante a sua experiência, que se sobrepõem aos conteúdos informativos veiculados pelos media.

O priming começa a ser teorizado nos meados dos anos 80 como continuidade dos estudos dos efeitos dos media, que se vinham desenvolvendo desde inícios dos anos 70. Trata-se, pois, de um conceito que procura esclarecer os efeitos dos media que surgem além do agendamento, socorrendo-se da Psicologia para clarificar o processo de ativação da memória recente no já referido procedimento de avaliação.

Weaver (2007) defende algumas considerações anteriores a 1987 no que se refere ao estudo da evolução do efeito de agenda na perceção e avaliação do público, que, no entanto, ganhariam forma, efetivamente, com o estudo de Iyengar e Kinder. Estes autores procederam à utilização de metodologias experimentais controladas para estudar o consumo de noticiários televisivos por parte de cidadãos americanos comuns, relacionando a análise de alguns temas pré-definidos com a forma como o público avaliava criticamente o presidente.

Em "News That Matters: television and American Opinion", Iyengar e Kinder defendem que, "ao chamar a atenção para alguns assuntos, ignorando os outros, as notícias televisivas influenciam os padrões pelos quais governos, presidentes, políticas e candidatos para cargos públicos são julgados. Priming refere-se a mudanças nos padrões que as pessoas usam para fazer avaliações" (1987: 63).

Os autores verificam, ainda, e através da sua experimentação, que habitualmente o efeito de priming é mais notado "quando as notícias enquadram um problema como se fosse um assunto da vida do presidente, quando os telespetadores estão preparados para considerar o problema como importante, e quando veem o problema como enredado nos deveres e obrigações da presidência" (1987: 97). Este processo dá-se, precisamente, a partir da imagem-despertador.

O efeito de priming debruça-se sobre o modo como certos esquemas mentais são ativados nos recetores da informação, através dos conteúdos informativos, e de como isso influi na permanência, mudança e intensificação das perceções e, posteriormente, das avaliações feitas pelo público em relação aos personagens da vida pública ou a um dado acontecimento mediático. Trata-se, pois, de um procedimento mental que vai além do simples processamento da informação rececionada, porquanto o priming se baseia na tentativa de explicar os efeitos dos media através da memória. Ou seja, o processo de priming diz respeito a um conjunto de processos de ativação de associações na mente do recetor da informação, dos quais procuramos isolar o momento que classificamos de imagem-despertador, que se destaca pela sua intensidade e pela sua capacidade disruptiva. E é a forma como estes processos são ativados, mediante determinados conteúdos, que vai determinar as referidas avaliações do público ou do recetor da informação.

Sobre este aspeto, Jo e Berkowitz (1996) referem a noção de "redes associativas", segundo a qual, "a apresentação de certos estímulos de certo significado favorece outros conceitos semanticamente relacionados, alimentando a probabilidade de invocar pensamentos de sentido semelhante aos estimulados pela própria apresentação" (p.70).

Neste sentido, o já referido processo de tipificação abordado por Schutz não se dá sem que haja um ou mais pontos de referência que permitam ao indivíduo fazer a associação imediata entre o momento presente e todo um referencial anterior. Porém, muitas vezes esse referencial anterior, justamente pela sua natureza latente e frequentemente inconsciente, carece de um estímulo forte. 
Surge, deste modo, aquilo a que Schutz (1972) chamou de sobressalto (leap ou shock) e que é provocado no campo dos media por aquilo a que chamamos imagem-despertador.

A imagem-despertador intensifica a perceção, originando uma segunda fase do processo cognitivo. Desperta memórias latentes na "bagagem" de conhecimentos adquiridos e, ao mesmo tempo, cria um esquema cognitivo de classificação e de atribuição de relevância às situações, influenciando simultaneamente os mecanismos de agendamento e de enquadramento.

Deste modo, desperta um efeito de priming, intensificando a importância do tema no processo de agendamento e origina simultaneamente novos frames.

O framing só pode existir se houver uma associação de ideias, ou seja, uma imagem-despertador, sendo que, o framing só se replica em relação a algo que existe anteriormente. Mas para que este efeito de priming se reproduza, para que o framing se gere, terá sempre que haver um elemento que permita o estabelecimento de redes associativas com memórias latentes. Muitas vezes, o processo de priming é inconsciente e o que o torna consciente é a imagem-despertador.

Por outro lado, as imagens-despertador nem sempre se revestem do mesmo impacto para o recetor, ou seja, haverá vários níveis de intensidade e de efeito provocado, mediante cada uma delas. Por outras palavras, poderemos considerar a construção e aplicação de uma tipologia de imagens-despertador.

Deste modo, num primeiro nível consideraríamos uma imagem-despertador de efeito imediato, como é exemplo a fotografia de Aylan Kurdi - que serve de base a esta análise -, que desperta automaticamente um sobressalto.

A um segundo nível colocaríamos uma imagem-despertador que, despertando um estímulo, provocaria no recetor uma perceção de identificação com a imagem e/ou situação - tal como no primeiro nível -, mas de uma forma distinta. Neste caso, a imagem-despertador não tem tanto impacto como a anterior e induz a busca de referências que permitam ao recetor atribuir lógica àquele sobressalto, mediante experiências vividas. Dá-se, então, uma espécie de enigma momentâneo que desperta a atenção.

Num terceiro e último plano, poderíamos considerar uma imagem-despertador que tende a provocar no recetor um efeito retardado de sobressalto. Se, num primeiro nível, o recetor é despertado instantaneamente, e num segundo, esse sobressalto é gerado por associação a um conjunto de referências passadas que confiram sentido à experiência, neste caso, estaríamos perante uma imagem-despertador de menor impacto e, de certa forma, "temporizada". O sobressalto provocado por este tipo de imagem-despertador seria, assim, ativado mais tarde, remetendo retrospetivamente o recetor para uma situação familiar.

\section{A travessia do Mediterrâneo: para uma contextualização da crise dos refugiados}

Em 18 de outubro de 2013, a Itália implementou a operação "Mare Nostrum" depois do naufrágio de um navio de migrantes clandestinos, onde morreram mais de 360 pessoas, que tentavam atravessar o Mar Mediterrâneo. Esta operação terminou um ano depois, após o aumento exponencial do número de refugiados e migrantes chegados ao sul de Itália e à recusa de financiamento por parte de vários países da União Europeia. 
A agência europeia de gestão da cooperação operacional nas fronteiras externas dos Estadosmembros da UE (Frontex) avançou para a missão de busca e salvamento, através da operação "Tritão", com três navios e dois aviões de vigilância. Dos 626 mil pedidos de asilo em 2014, os países-membros da União Europeia aceitaram 185 mil. Durante este ano, e segundo a Organização Internacional para as Migrações (OIM), morreram ou desapareceram mais de três mil pessoas durante a travessia do Mediterrâneo. No total, entraram na União Europeia mais de 280 mil migrantes.

Mas, foi o ano de 2015 que marcou decisivamente a crise dos refugiados. Fugindo da guerra da Síria, muitas pessoas abandonaram - frequentemente, de forma precária - o país, tentando procurar melhores condições de vida e, sobretudo, de segurança, um pouco por toda a Europa.

Durante este ano, cerca de um milhão de migrantes chegou à Europa, sobretudo através do Mar Mediterrâneo, naquele que é o maior fluxo migratório desde a II Guerra Mundial.

A 19 de abril de 2015, o naufrágio de uma traineira no Mediterrâneo tirou a vida a, pelo menos, 800 refugiados.

Em maio, a União Europeia lançou a operação EU Navfor Med - com base em Roma - com a missão de identificar, capturar e destruir embarcações utilizadas no tráfico de migrantes.

A 22 de junho é lançada a primeira fase da operação, com a missão principal de assinalar traficantes e controlar rotas e padrões do tráfico de migrantes, a partir de Líbia em direção a Itália e Malta.

Julho marcou o arranque da construção - por ordem do governo húngaro - de uma cerca de arame farpado ao longo da fronteira da Hungria com a Sérvia, por forma a travar a entrada de refugiados na Europa. No dia 20 deste mês os líderes da União Europeia acordaram receber 32.256 refugiados de Itália e Grécia. Em maio, o presidente da Comissão Europeia, Jean-Claude Juncker, tinha proposto 40 mil. No fim do mês, o primeiro-ministro britânico, David Cameron, alertava para aquilo que denominava "uma multidão de pessoas que atravessam o Mediterrâneo para ir para o Reino Unido".

Em agosto, os corpos de 71 sírios foram encontrados numa carrinha-frigorífica na Áustria. A 22 do mesmo mês, a ministra do interior britânica, Theresa May, anuncia uma operação conjunta de Reino Unido e França na fronteira (Calais) para aumentar a segurança das travessias do Canal da Mancha, após diversas tentativas e mortes de refugiados sírios que tentavam alcançar a Inglaterra.

No primeiro dia do mês de setembro, a estação ferroviária de Budapeste é encerrada, depois da chegada massiva de refugiados, tendo alegadamente entrado pelo menos 2300 de forma ilegal, dos quais 353 menores. Centenas de refugiados amontoam-se na estação de Keleti, protestando contra as autoridades húngaras e pedindo-lhes permissão para passar rumo à Áustria e Alemanha.

Um dia depois, deu-se provavelmente o acontecimento mais mediatizado desde que os refugiados começaram a sair massivamente dos seus países do norte de África e Médio Oriente rumo à Europa: o aparecimento, numa praia turca, do corpo de Aylan Kurdi, uma criança de três anos, que morreu afogada durante a tentativa da família de chegar à Grécia a partir da Turquia. Porventura, por se tratar de uma imagem forte de um cadáver de uma criança, este acontecimento desencadeou uma onda de solidariedade popular, alertando muitos europeus para a problemática dos refugiados. O slogan "Refugiados Bem-vindos" torna-se viral e David Cameron afirma que o Reino Unido cumprirá as suas "obrigações morais". 
Setembro foi também o mês da reabertura da principal estação de caminhos-de-ferro de Budapeste, após um encerramento de dois dias. Centenas de refugiados seguiam agora em comboios para a fronteira austríaca, outros partiam a pé com destino à Alemanha.

Nesta fase, o primeiro-ministro húngaro, Viktor Orban, afirmou que a crise é um "problema alemão". A 4 de setembro o parlamento húngaro aprovou mesmo uma série de leis que previam penas de até três anos de cadeia pela passagem ilegal das suas fronteiras. Um dia depois, a sociedade civil mobilizou-se e os atos de solidariedade sucederam-se, com o primeiro-ministro finlandês, Juha Sipilä, a oferecer a sua vivenda para albergar refugiados que chegassem à Finlândia solicitando asilo. O presidente Maryano Rajoy promete que Espanha será solidária.

A 7 de setembro, David Cameron diz que o Reino Unido vai receber mais 20 mil refugiados no prazo de cinco anos, e a França concorda receber 24 mil. A Alemanha, cuja chanceler Angela Merkel tinha apelado aos parceiros europeus para receberem migrantes, afirmou necessitar de seis mil milhões de euros para ajudar 800 mil refugiados, que espera acolher até final do ano.

Jean-Claude Juncker, presidente da Comissão Europeia, pediu, a 9 de setembro, aos Estados-membros que acolhessem mais 120 mil refugiados, elevando o total para 160 mil, a serem distribuídos com base num sistema de quotas. Os planos iniciais previam que três quintos dos novos refugiados fossem distribuídos entre a Alemanha, França e Espanha.

A 13 de setembro, um número recorde de 5.809 pessoas chegou à Hungria, quando a cerca na fronteira edificada pelo governo estava quase concluída. A Alemanha impôs controlos de emergência nas fronteiras com a Áustria, suspendendo temporariamente o acordo de Schengen. Responsáveis afirmaram que o país recebeu 63 mil refugiados desde o fim de agosto. Um dia depois, a Áustria e a Eslováquia anunciaram a reintrodução de controlos fronteiriços. A Alemanha avisou que poderia registar até um milhão de entradas nesse ano de 2015 e a Hungria declarou o estado de emergência, ameaçando prender quem entrasse ilegalmente no país. O dia 23 marcou a Cimeira da União Europeia, promovida para discutir o fenómeno migratório.

Em novembro, Ancara e a União Europeia estabeleceram um acordo que previa uma ajuda europeia de três mil milhões de euros para a Turquia. Em troca, as autoridades turcas comprometeram-se a melhorar o controlo das fronteiras e a cooperar na luta contra as redes de tráfico de pessoas.

Dezembro foi o mês do anúncio, por parte da União Europeia, de um projeto que pretendia controlar as fronteiras externas. Por outro lado, foi criado um mecanismo para deslocar de forma permanente os refugiados e sem qualquer limite quanto ao número. Este mecanismo obrigatório não foi aceite sem contestação em toda a Europa, com a Eslováquia e a Hungria a manifestarem o seu desagrado, enquanto a Áustria procedeu ao encerramento da fronteira com a Eslovénia.

O último mês de 2015 marcou também a chegada a Portugal dos primeiros (24) refugiados ao abrigo do programa da União Europeia, no dia 17.

\section{Aylan Kurdi: a força de uma imagem}

A foto de Aylan Kurdi, o menino sírio que se afogou numa praia turca e que consideramos ser um momento de viragem na agenda mediática da crise dos refugiados, foi tirada pela fotógrafa 
turca Nilüfer Demir, da agência Dogan, e difundida pela agência Reuters Ankara / DHA a 2 de setembro de 2015.

O caso de Aylan foi um entre milhões de sírios que fugiram do seu país em guerra. No caso desta criança de três anos de idade, fugia de Kobane com a sua família em direção à ilha grega de Kos.

De acordo com a Reuters, naufragaram 23 pessoas que viajavam em dois barcos. Morreram, inclusivamente, cinco filhos e uma mulher, sendo que Aylan Kurdi nem foi o mais novo a afogar-se nas águas do Mediterrâneo. No mesmo barco viajavam os gémeos Jafer, que tinham ano e meio. Os cadáveres estavam na praia turca em Bodrum, Província de Mugla.

Duas mil pessoas passaram pelo mediterrâneo em pequenos barcos de borracha nas quatro semanas anteriores, mas foi Aylan Kurdi a provocar um boom mediático da tragédia dos refugiados. Até ao aparecimento e difusão do cadáver desta criança síria, a crise dos refugiados era noticiada como um todo, como uma massa de pessoas que ia sucumbindo nas águas do Mar Mediterrâneo. A partir do dia 2 de setembro de 2015, o mundo passou a (re)conhecer um rosto, um corpo, um nome que personifica toda esta tragédia: Aylan Kurdi.

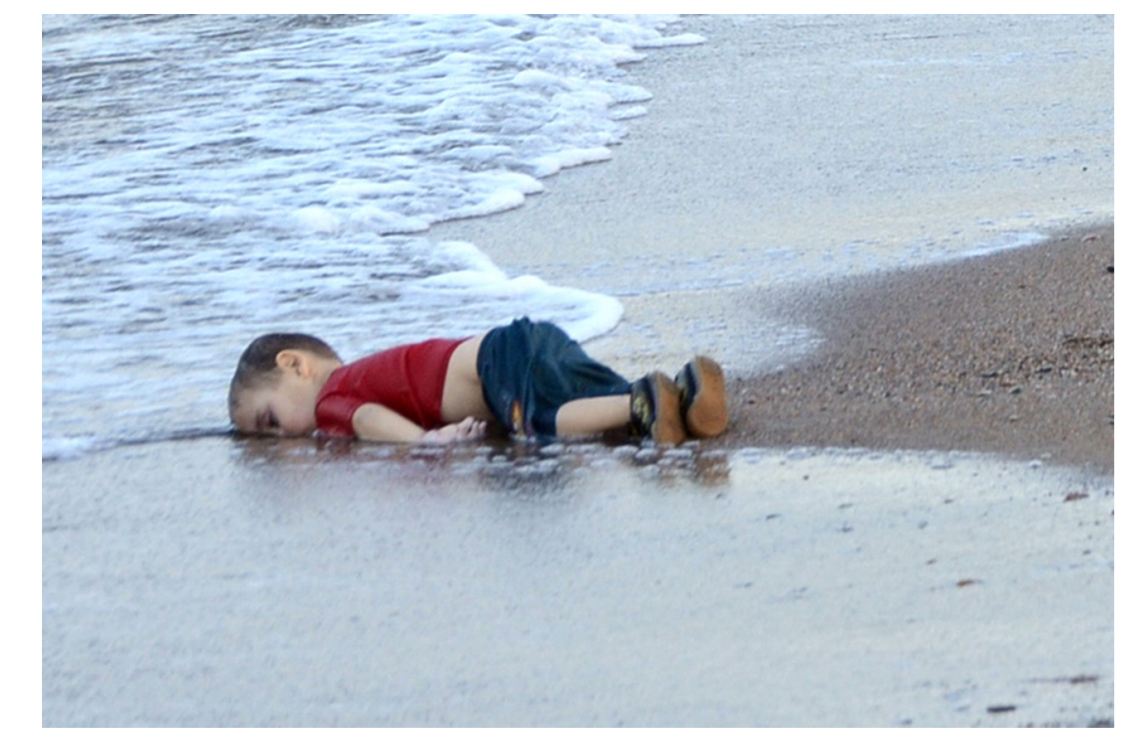

Imagem 1. Fotografia de Aylan Kurdi, da autoria de Nilüfer Demir / Agência Dogan (Reuters, 2015).

Foi difundida pela maioria dos principais meios de comunicação de todo o mundo, numa quantidade assinalável de primeiras páginas e notícias. Os principais jornais de Portugal e Espanha - Público e El País, respetivamente - mantiveram esta tendência.

Mas antes mesmo de aparecer nos jornais, esta imagem acaba por se espalhar de forma viral pelas redes sociais. De tal forma, que a Reuters enfatizou o próprio poder da "viralização", escrevendo: "A imagem perturbadora de uma criança capta o olhar, horroriza" (Reuters, 2015). 


\section{Aylan Kurdi e o enquadramento ibérico}

No estudo da existência de um enquadramento importa compreender como os níveis sociais e cognitivos se expressam ao nível do enunciado. Tal conduz diretamente à construção de um modelo de análise do discurso - isto é, uma análise linguística que permita "produzir descrições sistemáticas e explicitas de unidades de linguagem”. (Correia, 2011: 92; van Dijk, 1988: 24).

Uma ideia fundamental que cabe ter presente é que um texto é uma teia complexa cuja unidade não parte do mero encadeamento de orações. Há textos que constam de uma única oração ou de uma só palavra, enquanto outros são formados por muitas. No plano mais vincadamente linguístico, pretende descrever a estrutura do discurso como uma sequência de frases que se seguem umas às outras numa ordem específica e com relações de condicionamento recíproco (Cfr. van Dijk, 1997: 2-4). Tal implica a referência à noção de coerência como conjunto de recursos para construírem relações no discurso que transcendem a estrutura gramatical.

É possível estudar as relações de coerência em frases que se seguem umas às outras (micronível de análise) ou o conteúdo do discurso como um todo (macro-nível de análise), explicando como o discurso se torna algo significativo que transcende um conjunto incoerente de frases. (Correia, 2011: 92-93). Estas relações de coerência implicam a emergência num texto, de um nó unificador que dá sentido à totalidade do discurso, do texto ou, até, que unifica diversos textos entre si. O papel de nó unificador dos diferentes textos entre si e, dentro de cada texto, dos diferentes tópicos que o compõem é a referência a Aylan, "o menino turco".

A 3 de setembro de 2015, no dia seguinte ao naufrágio que vitimou Aylan, o Público dá conta da história por detrás do número, algo que não acontecera até então. Escrevia o diário na sua versão online: "Família do menino afogado estaria a tentar chegar ao Canadá - Jornalistas na Turquia, Canadá e Síria contam que a família do pequeno Aylan viu recusado um pedido de asilo em Junho. Só o pai sobreviveu". 


\section{Família do menino afogado estaria a tentar chegar ao \\ Canadá}

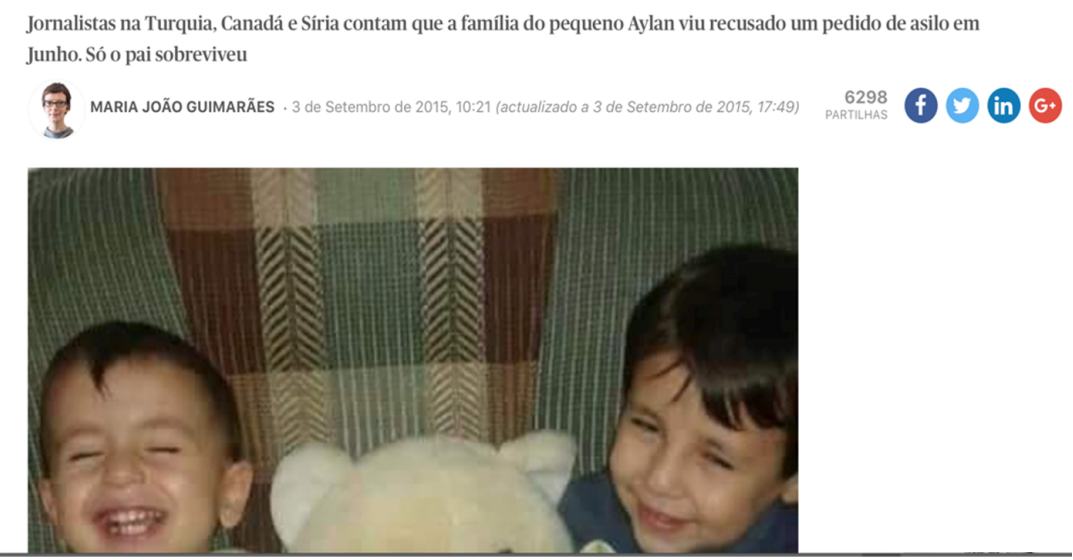

Imagem 2. Printscreen da notícia do Público de 3 de setembro de 2015.

Até este momento, os refugiados e as suas mortes eram invariavelmente contados aos milhares e os refugiados considerados uma massa de pessoas, sem rosto, sem nome. Deles apenas se sabia que fugiam da guerra, sendo muitas vezes confundidos e associados ao fenómeno de terrorismo do qual fugiam.

Com a divulgação da fotografia do cadáver desta criança síria, surge finalmente um rosto e um nome por detrás de uma tragédia que já se vinha desenrolando e provocando milhares de mortes. Contudo, só uma mereceu um impacto mediático considerável: Aylan Kurdi. Escreve a 3 de setembro o jornal Público, na mesma notícia: "O menino que morreu afogado depois de o seu barco naufragar entre a Turquia e a ilha grega de Kos tornou-se o símbolo de muitas mortes invisíveis e anónimas, de um fluxo de pessoas desesperadas por chegar à segurança de um país em paz". A adjetivação utilizada - "mortes invisíveis e anónimas" (...) "pessoas desesperadas" - adensa a importância de Aylan Kurdi para o despertar mediático da crise dos refugiados, a importância que a imagem do cadáver desta criança teve para, no fundo, ajudar a consciencializar o mundo para este problema. O "menino turco" não apenas ajuda a dar consciência do problema, facilita a aquisição dessa mesma consciência enquanto referencial e agregador dos diferentes textos e tópicos que se reproduzem ao nível do caso dos refugiados.

No fecho da notícia, a coerência textual e discursiva é obtida através de uma declaração do pai de Aylan Kurdi (e de um outro irmão que também perdeu a vida no naufrágio), que coloca o leitor na posição daquela pessoa que acabara de perder os dois filhos: "'Os meus filhos eram as crianças mais bonitas do mundo. Há alguém no mundo que não considere os seus filhos a coisa mais preciosa da vida?', disse Abdullah. 'Eu perdi tudo"'.

Um dia depois, é o espanhol El País a publicar uma notícia, tendo como protagonista o pai de Aylan Kurdi, que morrera com outro irmão (facto que os meios de comunicação referem quase em 
jeito de informação adicional, o que também nos ajuda a perceber a função da imagem do menino morto).

\section{"Las manos de mis dos niños se escaparon de las mías"}

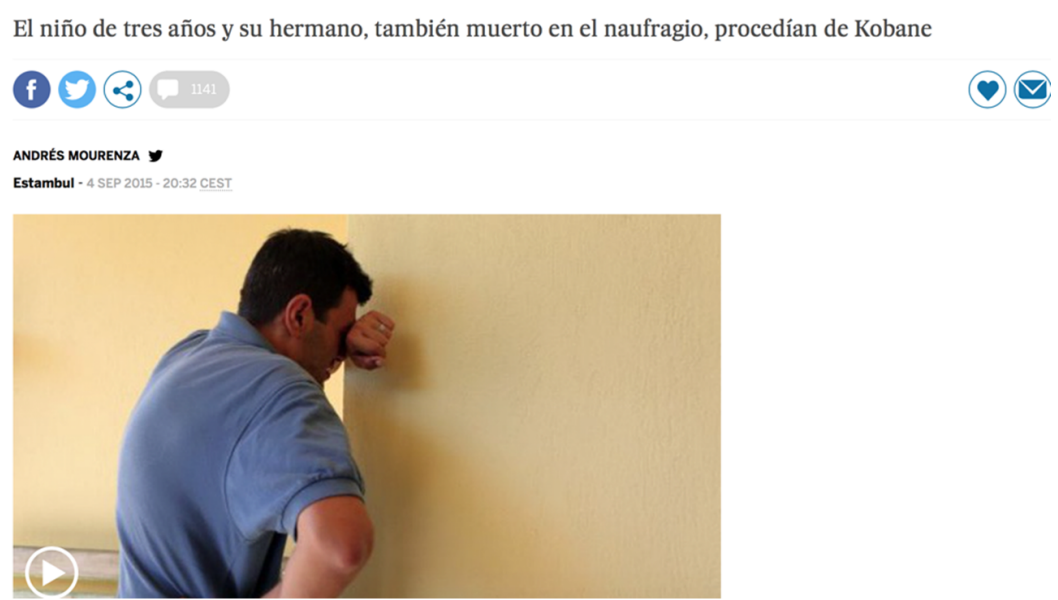

Imagem 3. Printscreen da notícia do El País de 4 de setembro de 2015.

O tópico relativo à proximidade à tragédia de um pai que perde os seus dois filhos pequenos é-nos dada através do título: "As mãos dos meus dois filhos escaparam-se das minhas"; é retomado no primeiro parágrafo, descritivo, através da referência ao sentimento e à solidariedade para com um menino que "só tinha três anos".

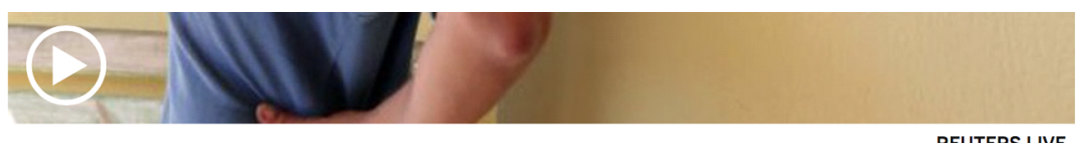

\footnotetext{
Sobrevivió a las bombas y a la guerra, pero no al mar ni a las barreras geográficas y legales que separan un Oriente Próximo en llamas de Europa. El niño sirio cuya fotografía se ha convertido en el símbolo del drama de los refugiados -con su diminuta camiseta roja y su pantalón azul, tendido sin vida en la turística playa turca de Ali Hoca Burnu, lamiéndole la cara las mismas olas del mar que lo mataron- ha sido identificado como Aylan Kurdi. Solo tenía tres años. Su familia había intentado pedir asilo en Canadá.
}

Imagem 4. Printscreen da notícia do El País de 4 de setembro de 2015.

"Sobreviveu às bombas e à guerra, mas não ao mar nem às barreiras geográficas e legais que separam um Médio Oriente em chamas da Europa. O menino sírio cuja fotografia se converteu no símbolo do drama dos refugiados - com a sua diminuta camisola vermelha e o seu calção azul, 
estendido sem vida na turística praia turca de Ali Horca Burnu, lambendo-lhe a cara as mesmas ondas de mar que o mataram - foi identificado como Aylan Kurdi. Só tinha três anos. A sua Família tinha tentado pedir asilo no Canadá".

Este parágrafo resume, per si, o enquadramento dado pelos media a esta crise dos refugiados - e, neste caso, tanto pelo jornal Público, como pelo El País -, proporcionado pelo aparecimento e difusão da fotografia de Aylan Kurdi, um menino que tinha sobrevivido à dura realidade de um país em guerra, mas que não resistira às barreiras geográficas - e (parece surgir nas entrelinhas) políticas - que separam o Médio Oriente da Europa. Este é um menino que sucumbe nas mesmas águas, na mesma praia onde outros - mais afortunados - habitualmente se banham durante as férias.

Esta função desempenhada pela imagem e pelo nome de Aylan torna-se mais uma vez clara a 22 de setembro de 2015, quando o jornal Público noticia: "Caravana Aylan Kurdi já chegou à Croácia com ajuda portuguesa - Viajaram quase 60 toneladas de roupa, calçado, comida, artigos de higiene, medicamentos e brinquedos";

\section{Caravana Aylan Kurdi já chegou à Croácia com ajuda portuguesa}

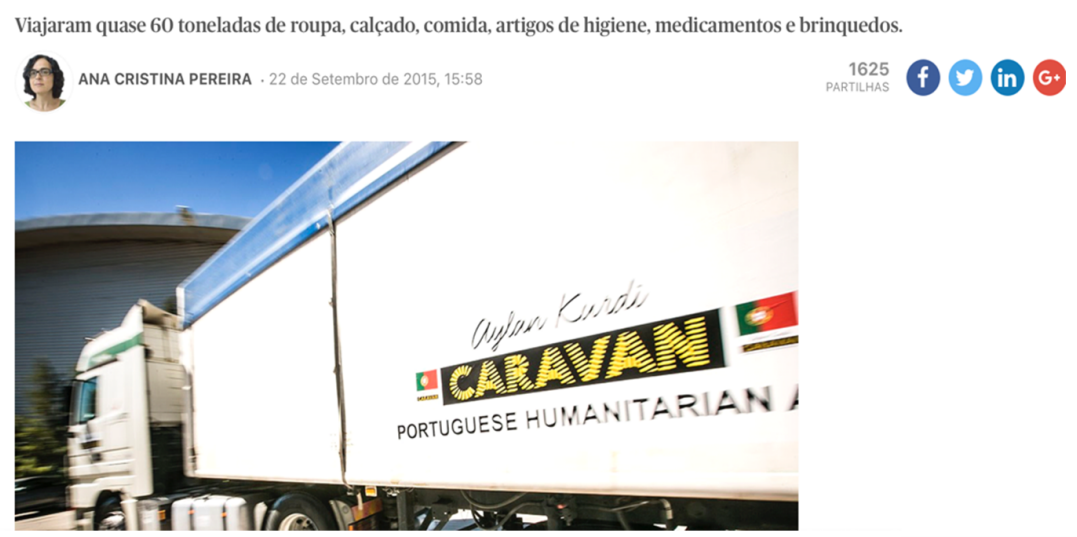

Imagem 5. Printscreen da notícia do Público de 22 de setembro de 2015.

e um dia depois, a 23 de setembro: "Inatel prepara-se para dar formação e emprego a 100 refugiados - Programa Aylan da fundação inclui desenvolvimento de cursos profissionais em hotelaria para dotar refugiados de competências. No final, serão assinados contratos de trabalho. Cada uma de 12 unidades ficará responsável por uma família". 


\section{Inatel prepara-se para dar formação e emprego a 100 refugiados}

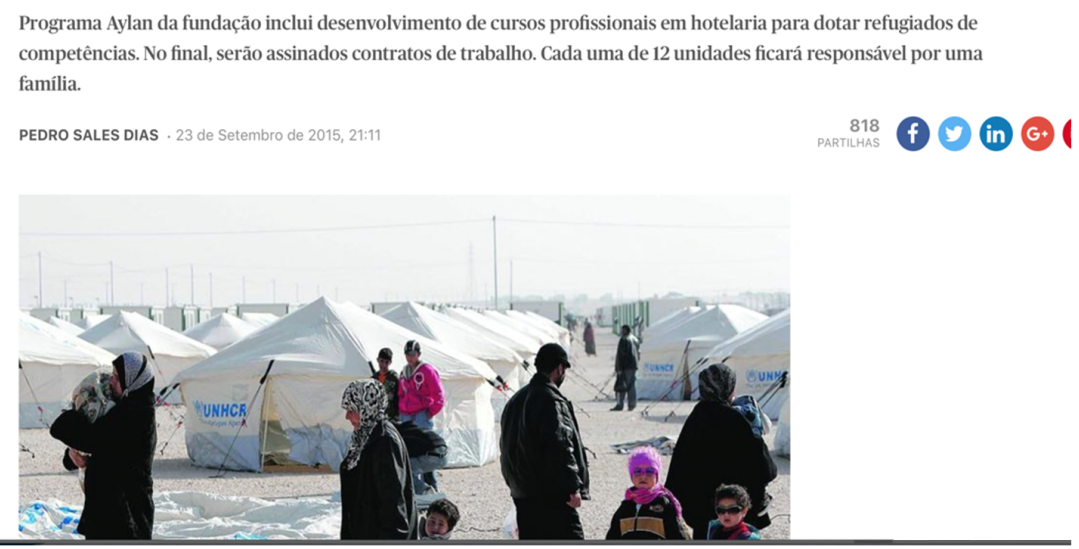

Imagem 6. Printscreen da notícia do Público de 23 de setembro de 2015.

Portanto, aqui denota-se, por um lado, a preocupação humanitária existente em torno dos refugiados, mas, sobretudo, a função de agregador e de "despertador" que, mais uma vez, Aylan Kurdi assume nesta crise. Em dois dias surgem as notícias da "Caravana Aylan Kurdi" e o "Programa Aylan”, promovido pela Fundação Inatel.

Finalmente, a função desempenhada pela imagem de Aylan Kurdi na economia enunciativa dos media e na construção de uma "rede de facticidade noticiosa" em seu redor (Correia, 2011: 94) torna-se visível pelo facto de perdurar como referência dinâmica que unifica eventos diversos ao longo do decurso do tempo.

Cerca de um ano depois do naufrágio, o Público dava eco do pedido de mais humanidade. Escreve o jornal, na sua versão online de 16 de setembro de 2016: "Um ano depois de Aylan, são cada vez mais os muros para travar refugiados - As mortes no Mediterrâneo aumentaram, apesar de serem menos os que tentam chegar à Europa. Assembleia-geral da ONU arranca com iniciativas que pedem mais coordenação e uma abordagem "mais humana". Há mais de 65 milhões de refugiados no mundo, uma em cada 113 pessoas". 


\section{REFUGIADOS \\ Um ano depois de Aylan, são cada vez mais os muros para travar refugiados}

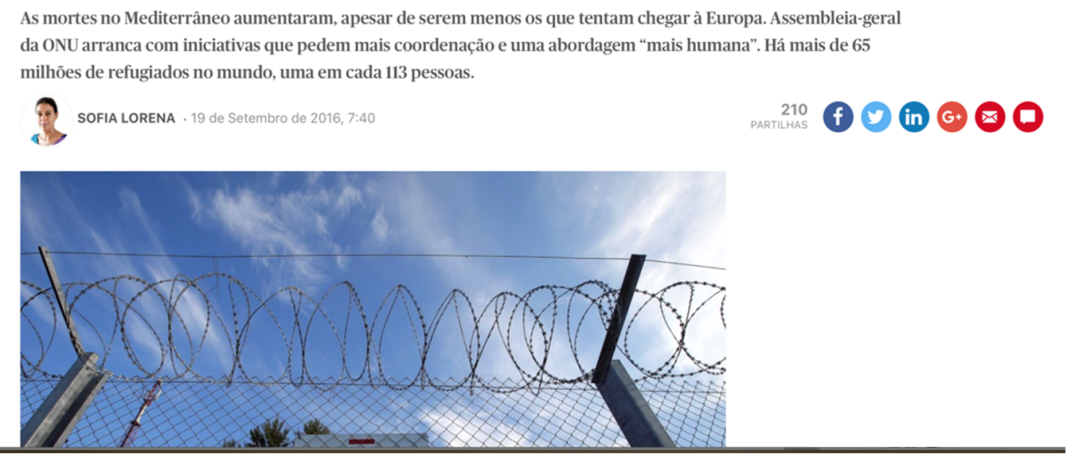

Imagem 7. Printscreen da notícia do Público de 19 de setembro de 2016.

A notícia publicada no jornal Público a 19 de setembro de 2016 dá conta da aparente recetividade dos cidadãos europeus, para a qual contribuiu sobremaneira o aparecimento do cadáver de Aylan Kurdi, na lógica - já aflorada - do despertar de consciências para este flagelo social. "O que parece haver é um desencontro entre o entendimento dos políticos e a opinião pública: de acordo com uma sondagem encomendada pelo International Rescue Committee (e feita pela empresa Ipsos Mori), mais de três quartos dos europeus (em 12 países) percebem que os seus países recebam refugiados e empatizam com eles. 'Esta sondagem mostra que os europeus não perderam os seus corações', diz David Milliband, presidente do IRC. 'A crise de refugiados é uma tragédia humana, não tem de ser um desastre político'. Aylan Kurdi abanou mesmo consciências - falhou foi a de alguns políticos”, pode ler-se.

Dentro da mesma lógica de assinalar uma data que era reconhecidamente de viragem na crise dos refugiados, exatamente um ano depois do aparecimento do corpo do menino sírio, a 2 de setembro de 2016 e edição online do El País fazia de Aylan Kurdi uma espécie de metonímia do sofrimento das crianças refugiadas: "Um ano depois, mais de 400 Aylan morreram afogados no mediterrâneo", escreve. No subtítulo, um lamento do pai do menino sírio, adensa a necessidade de se fazer algo mais pelos refugiados: "Todo o mundo queria fazer algo. A fotografia do meu filho morto comoveu o mundo, mas continuamos a morrer e ninguém faz nada". 


\section{E ELPAIIS $\quad$ DE MAMAS Y DE PAPAS a : a \\ Un año después más de 400 'Aylan’ han muerto ahogados en el Mediterráneo}

“Todo el mundo quería hacer algo. La foto de mi hijo muerto conmovió al mundo, pero la gente sigue muriendo y nadie hace nada", dice el padre a la prensa alemana

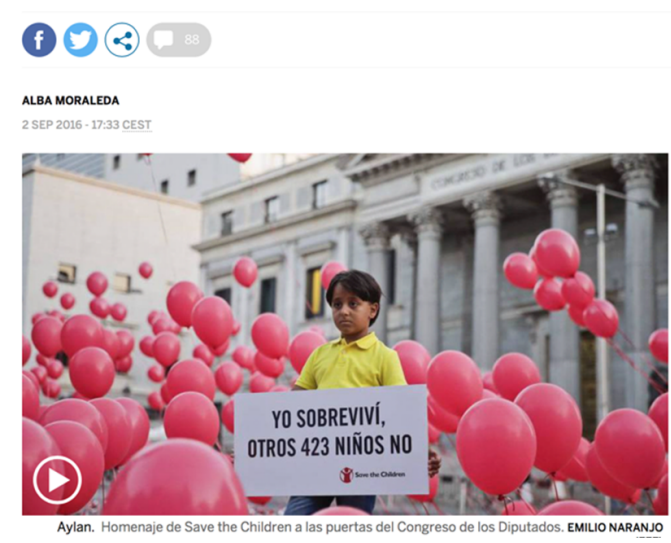

Imagem 8. Printscreen da notícia do El País de 2 de setembro de 2016.

Destaque-se a imagem utilizada de uma criança em frente à porta do Congresso dos Deputados, em Espanha, numa manifestação promovida pela organização Save The Children. Tal como há um ano na praia turca de Ali Horca Burnu, mais uma vez um rosto: "Eu sobrevivi. Outros 423 meninos, não", pode ler-se num cartaz empunhado pela criança.

O marco de referência comum que associa estas histórias é a partilha de um ícone comum que serve para referir a crise dos refugiados através de um enquadramento em que sobressai o sentimento de solidariedade e de compaixão para com os mais frágeis: as crianças. Simultaneamente, esse enquadramento só pode ser ativado por referência a este ícone partilhado, que ativa as memórias relativas ao sofrimento infantil. Ou seja, o enquadramento é retomado cada vez que a imagem de Aylan despoleta uma rede associativa, uma conexão psicológica com o sentimento de compaixão para com esse sofrimento. O mesmo que o priming sustenta e serve de trave a uma rede associativa que permite formular um determinado enquadramento.

\section{Considerações finais}

A crise dos refugiados tem feito ao longo dos últimos anos milhares de vítimas mortais, que sucumbem no Mar Mediterrâneo e ficam a meio no sonho europeu de maior segurança e paz. No entanto, Aylan Kurdi e a divulgação da fotografia do seu corpo numa praia turca a 2 de setembro de 2015 veio dar outra dimensão mediática a esta tragédia.

A partir da análise às versões online dos principais jornais de referência de Portugal e Espanha - Público e El País, respetivamente - percebemos o poder transformador da imagem de Aylan Kurdi, que adquiriu mesmo uma dimensão política e se tornou numa bandeira de manifestação coletiva em torno do problema dos refugiados. 
De notar que este acontecimento mediático surge após vários anos de guerra na Síria, tornandose o símbolo de um problema social à escala global e a que a comunicação social deu eco e forma.

Aylan Kurdi promoveu, inclusivamente, a solidariedade num contexto que não é novo. A imagem desta criança conseguiu, ainda, alterar o enquadramento criado em torno da crise dos refugiados, considerados até então como um todo, como uma massa de pessoas sem rosto ou nome. Alterou-se o frame, o ângulo, a visão do problema. Passámo-nos a sentir identificados, próximos desta tragédia.

Personificando toda a crise dos refugiados, a fotografia de Aylan Kurdi funcionou como aquilo a que podemos chamar de imagem-despertador.

A imagem-despertador, criada pelos media, despertou redes associativas que terão permitido o surgimento de um efeito de priming e, simultaneamente, desencadear um framing. Porque não há framing sem memória, sem referências à priori, para que o processo de enquadramento (framing) se verifique tem que se dar primeiro o reconhecimento cognitivo, o qual não surge espontaneamente, mas de algo que já está latente na memória do sujeito.

Neste sentido, o framing associa-se ao priming - que, por sua vez, dá origem a uma série de ideias -, mas é graças ao impacto de uma imagem-despertador que o priming é desencadeado, originando um novo framing mediático, mediante o qual a imagem do cadáver de Aylan Kurdi na praia passa a ser associada à crise dos refugiados. Assim, precisa do efeito de priming para se dar a associação de ideias que garantam a sobrevivência do framing. É, neste ponto, que poderá emergir a importância da imagem-despertador no campo jornalístico. O despertador é aquilo que provoca um sobressalto na consciência. Aylan Kurdi foi a imagem-despertador da crise dos refugiados, contribuindo decisivamente para uma tomada de consciência acerca desta problemática.

A imagem de Aylan Kurdi terá mesmo reconfigurado a forma como a própria crise dos refugiados passou a ser veiculada pelos meios de comunicação social e a partir da qual o mundo se consciencializou para aquele que é o maior fluxo migratório desde a II Guerra Mundial e que ceifou milhares de vidas.

\section{Referências Bibliográficas}

(2015, dezembro 27). Cronologia: Crise dos refugiados na Europa em 2015. Jornal de Negócios. Disponível em: www.jornaldenegocios.pt/economia/europa/detalhe/cronologia_crise_dos_re fugiados_na_europa_em_2015. Consultado a 20 de março de 2018.

(2015, setembro 2). Troubling image of drowned boy captivates, horrifies. Reuters Disponível em: http://reut.rs/1ExFCO8. Consultado a 20 de março de 2018.

Bateson, G. (1972). A theory of play and fantasy. Psychiatric research reports, 2, 39- 51. New Jersey: Janson Aronson Inc..

Correia, J. C. (2011). Teoria e crítica do discurso noticioso. Covilhã: LabCom Editora.

Dias, P. S. (2015, setembro 23). Inatel prepara-se para dar formação e emprego a 100 refugiados. Público. Disponível em: https://www.publico.pt/2015/09/23/sociedade/noticia/inatelpreparase-para-dar-formacao-e-emprego-a-100-refugiados-1708821. Consultado a 22 de março de 2018. 
Entman, R. M. (1993). Framing: toward clarification of a fractured paradigm. Journal of Communication, 43(4), 51-58. https://doi.org/10.1111/j.1460-2466.1993.tb01304.x.

Goffman, E. (1974). Frame analysis: an essay on the organization of experience. Boston: Northeastern University Press.

Guimarães, M. J. (2015, setembro 3). Família do menino afogado estaria a tentar chegar ao Canadá. Público Disponível em: www.publico.pt/2015/09/03/mundo/noticia/familia-do-menin o-afogado-da-imagem-estaria-a-tentar-chegar-ao-canada-1706729. Consultado a 22 de março de 2018.

Iyengar, S. \& Kinder, D. R. (1987). News that matters: television and american opinion. Chicago, University of Chicago Press.

Jo, E. \& Berkowitz, L. (1996). Análisis del efecto priming sobre la influencia de los media: una puesta al día. In J. Bryant \& D. Zillmann (orgs.), Los efectos de los médios de communicación - investigaciones y teorias (pp. 67-88). Barcelona: Paidós.

Lorena, S. (2016, setembro 19). Um ano depois de Aylan, são cada vez mais os muros para travar refugiados. Público. Disponível em: https://www.publico.pt/2016/09/19/mundo/noticia/umano-depois-de-aylan-refugiados-sao-mais-e-encontram-ainda-mais-muros-1744453. Consultado a 22 de março de 2018.

McCombs, M. \& Ghanem, S. I. (2001). The convergence of agenda setting and framing. In S. Reese, O. Gandy \& A. Grant (eds.), Framing public life. Perspectives on media and our understanding of the social world (pp. 67-81). Mahwah, New Jersey: Lawrence Erlbaum Associates.

Moraleda, A. (2016, setembro 2). Un año después más de 400 'Aylan' han muerto ahogados en el Mediterráneo. El País Disponível em: https://elpais.com/elpais/2016/09/02/mamas_papas/14 72793420_323195.html. Consultado a 22 de março de 2018.

Mourenza, A. (2015, setembro 4). Las manos de mis dos niños se escaparon de las mías. El País. Disponível em: https://elpais.com/internacional/2015/09/03/actualidad/1441232434_109669 .html. Consultado a 22 de março de 2018.

Pereira, A. C. (2015, setembro 22). Caravana Aylan Kurdi já chegou à Croácia com ajuda portuguesa. Público. Disponível em: www.publico.pt/2015/09/22/sociedade/noticia/aylan-kurdicaravan-ja-chegou-a-croacia-1708621. Consultado a 22 de março de 2018.

Schutz, A. (1979). Fenomenologia e relações sociais - textos escolhidos de Alfred Schutz. Rio de Janeiro: Zahar Editores.

Schutz, A. (1976). Collected papers: studies in social theory, vol. II. The Hague, Martinus Nijhoff.

Schutz, A. (1972). On multiple realities. In M. A. Natanson \& H.Ł. van Breda (eds.), Collected papers I. The problem of social reality (pp. 207-259). Deordrecht: Springer.

Tuchman, G. (1978). Making news, a study in the construction of reality. New York: The Free Press. 
van Dijk, T. (1997). Discourse studies: a multidisciplinary introduction. Sage Publications.

van Dijk, T. (1988). News as discourse. Hillsdale, NJ: Lawrence Erlbaum Associates.

Weaver, D. H. (2007). Thoughts on agenda setting. framing, and priming. Journal of Communication, 57(1), 142-147. https://doi.org/10.1111/j.1460-2466.2006.00333.x. 